\title{
TEACHER ENHANCEMENT OF INTERACTIONS IN LIFE SCIENCES ENGLISH-SECOND-LANGUAGE LEARNERS CLASSES
}

\author{
Vuyo Kamati, \& Lydia Mavuru \\ Department of Science and Technology Education, University of Johannesburg (South Africa)
}

\begin{abstract}
Classroom interactions shape the teaching and learning process in science classrooms and can be influenced by the language of teaching and learning, and the teachers' choice of teaching strategies. Teaching Life Sciences to English-second-language learners can be a challenge when learners do not have a rich vocabulary of the medium of instruction. The use of English language by second-language-speakers have a negative impact on meaningful classroom interactions especially in the case of township school learners. Previous researchers alluded that Africa remains the only continent where formal education is conducted in instructional languages that are foreign to most learners and their teachers. In particular, some researchers found that poor performance of South African learners in science and mathematics are related to deficiencies in the language of instruction. Interactions encourage the exchange of talk, teachers' and learners' roles and simultaneously develops learners' cognition skills for effective communication in the science classrooms. Through sharing their own ideas, learners co-construct new scientific knowledge. Not only do these English-second-language speakers struggle with the medium of instruction which is different from their home languages, they also struggle to understand the technical and non-technical language of science, which compounds the problem. The current study sought to document how teachers assist learners in such classroom contexts. The study was guided by the research question: How do teachers assist learners in enhancing meaningful interaction in life sciences classrooms with English-second-language learners? In a qualitative case study, two Grade 11 Life Sciences teachers were purposefully selected from two different schools. Each teacher was observed whilst teaching two lessons to a Grade 11 Life Sciences class and then interviewed once to make a total of four lesson observations and two interviews. Data was analysed using Saldana (2009) manual coding. The findings showed that teachers engaged learners in question and answer sessions, debates, class discussions and class presentations to motivate them to communicate their ideas. Code switching was also used to explain the concepts in both English and learners' home languages. Some of the teachers acknowledged that learner participation was minimal due to their lack of fluency in English. Classroom interactions improved when learners were allowed to discuss in their home languages. The findings help in building a repertoire of teaching strategies teachers can employ in a class of English-second-language speakers.
\end{abstract}

Keywords: Classroom interactions, life sciences, English-second-language speakers, township.

\section{Introduction}

With the importance of English in today's world, teachers look for a significant method to meet the demand of learners using this language for communication. However, the use of the English language by second language speakers may have a negative impact leading to ineffective classroom interaction (Lee, 2000), especially in the case of township school learners. This is because township school learners are second if not third speakers of the English language and having to learn sciences in English may have an impact in learners not fully participating in the teaching and learning, and resulting in less classroom interaction. Language of instruction is a powerful tool of transmitting knowledge and communicating within a classroom (Resane, 2016), because it ensures active and positive classroom interaction between learners-teachers and between learners-learners. According to Yore and Treagust (2006) the utterances of both teachers and learners within a classroom are important in ensuring effective teaching and learning and positive learner interaction in class. However, the utterances need to be on a common ground and uttered in a common language to ensure understanding. 


\section{Literature review}

According to Wells and Arauz (2006) classroom discourse, language use and interaction are the basis of good teaching and learning. Teachers' ability to fuse all of them within the teaching and learning will ensure active learner participation within the lesson. Classroom is a built atmosphere where formal learning process takes place. It is an important environment where learners and teachers, learners and their peer groups come into contact to share information in their quest for knowledge, this relates to. Classroom interaction involves reciprocal actions that take place in a room between the teacher and the learners. This implies that the teacher formally instructs the learners, while the learners react in response to the teacher's instruction. According to Poonam and Sarita (2017) classroom interaction refers to the interaction between the teachers and learners and amongst the learners in the classroom. This interaction is a practice that enhances the development of two very important language skills which are speaking and listening. Main purpose of classroom interaction is encouraging the learners to communicate with their peers and teachers easily. The role of the teacher is to create an enabling learning atmosphere inside the classroom that motivate learners to come out with new ideas related to the topic.

The use of interactive technologies, including smartphones, tablets, interactive whiteboards, and classroom response systems by teachers have generated active discussions that focus on enhancing classroom interaction of learners and their learning performance and abilities (Gikas \& Grant, 2013). Many teachers use these interactive technologies because their versatility and mobility may afford learners active and collaborative experiences in the classrooms. However, not all South African schools have access to such advanced interactive technologies. Many teachers apply various techniques in their classroom with the aim of enhancing interactions within their classes. The various techniques which teachers apply in their respective classes create a borderless classroom which enables the students to freely explore knowledge without limits or boundaries. The study sought to answer the research question: How do teachers assist learners in enhancing meaningful interaction in these life sciences classrooms?

\section{Methodology}

The study used a mixed method research design (Creswell, 2014), which is a combination of both quantitative and qualitative research designs. The use of this design was appropriate as it combined the strengths of both quantitative and qualitative methods to compensate for their limitations (Pluye \& Hong, 2014). Using the quantitative method, the researcher collected data through classroom observations, analysed, and interpreted the data to determine the methods teachers use in enhancing meaningful interaction in Grade 11 life sciences classrooms with English-second-language learners. In addition, the researcher also collected qualitative data through interviews to authenticate the actions observed in the lessons and any misunderstanding that were encountered.

\subsection{Context of the study}

The study involved two township high schools in a district in Klerksdorp. From each school, two Grade 11 classes were selected for the study. In total the sample included four Grade 11 classes and two teachers. The two township schools enroll learners of different home languages placed in different classes. One class comprises of Setswana/Sesotho speakers and the other isiXhosa/isiZulu speakers. Both schools use English as a medium of instruction. The nature of the sample is suitable for the study because of the diversity of both learners and teachers in terms of home languages, values, economic status, and culture, which may influence the degree of the classroom interactions (collaborative, individual, authoritative, and dialogic) that take place during the teaching and learning process.

\subsection{Data collection}

Data collection involved a single two-45-minute lesson observation for each of the four classes. During the classroom observation, the researcher observed the four communicative approaches as espoused by Mortimer and Scott (2003). The four communicative approaches which were being observed during observations were: Interactive/Authoritative (IA), Non-interactive/Authoritative (NA), Interactive/Dialogic (ID) and Non-interactive/Dialogic (ND). For each school, each teacher was observed teaching lessons and all the lessons were observed in one day during separate times. The researcher observed how the learners responded to the teachers' questions and how teachers responded to the learners' questions, and made use of learners' responses to enhance further communication in terms of authoritative or dialogic approaches. The second phase of data collection involved structured interviews with the teachers to allow teachers to articulate how they assisted learners in enhancing meaningful interaction in their classrooms. The interviews were done after the observations on the same day, to seek clarity on the observed acts, and also to authenticate data from the lessons observed. 


\subsection{Data analysis}

Based on the results from the analysis of lesson observations, interview data was coded, in order to classify the reasons and elaborations given by teachers about the observed classroom communicative approaches in their lessons. Aspects of language difficulties were examined, which were some of the reasons that the teachers gave. Analysis of the discourse of the science lessons involved an iterative process of moving backwards and forwards through time, trying to make sense of the episodes as linked chains of interactions. Tehmina (2003) identified this coding method of data analysis as a crucial aspect of analysis, which is effective in organising and making sense of textual data obtained through observations. The researcher used a coded-method in analysing the data from the interviews. Similar responses uttered by the teachers were grouped in similar codes, while codes sharing the same characteristics were grouped into categories. Similar categories were then grouped into themes.

\subsection{Findings}

The presentation is done according to themes that were drawn from the analysis of interview data to 'unpack' classroom interaction patterns in Grade 11 life sciences English-second-language learners' classes. It should however be noted that the researcher also included some information gleaned from the four lessons observed, which were then authenticated by findings from the interviews. The language of teaching and learning influenced the level of classroom interaction in all four lessons observed from the two schools. In seeking clarity from the observed discourses, and obtaining the teachers' views on certain aspects of the language of teaching and learning in their classrooms, the two participating educators in this study were interviewed. The researcher wanted to assess how the two teachers assist learners in enhancing meaningful interaction in Grade 11 life sciences classrooms with English-second-language learners. The set of questions which the researcher asked the teachers were centred on the language of teaching and learning, and how it influences the level of classroom interactions within their classes.

During the interview, Mrs Ngubo acknowledged code-switching during her lessons and she strongly emphasised that she code-switched only to enable her learners to grasp the scientific concepts being taught. Mrs Ngubo fears that by allowing her learners to participate in their mother-tongue or code-switch to their mother-tongue will make them answer their assessments in their home-languages. Mrs Ngubo prefers the use of English over the learners' home languages, this could because Mrs Ngubo does not understand the benefits of allowing learners to code switch their home-languages. Code-switching should be viewed as fostering understanding.

Mrs Ngubo in the interview was asked what strategies she applies in order to enhance classroom interaction in her lessons was the use of drawings and charts and place them on the board and ask the learners to identify whatever concept they will be treating and that time. According to Mrs Ngubo, she believed that such strategy helps. The strategies Mrs Ngubo mentioned were not evident in the two lessons observed, what was seen in the lessons was Mrs Ngubo dominating classroom talk.

From the two lessons observed it was difficult to believe that Mrs Ngubo do apply the strategies she mentioned to actively engage the learners in lessons. Mrs admitted to allowing her learners to code-switch whenever they do not understand but in grade 11A Mrs Ngubo requested one of the learners to give an answer to the question she asked in English and the learner opted to sit down.

During the interview, Mr Nthorela emphasised that he understands his learners' background and he knows what to do, and when to do it, in order to engage his learners during the lesson. Mr Nthorela stated that he often encourages his learners to read more informative newspapers and magazines in order for the learners to familiarise themselves with the English language. Mr Nthorela's method of encouraging learners to read and familiarise themselves with English supports Richard's (2006) assertion that learners should be encouraged to take the initiative to participate and dare to express their ideas, it does not matter whether they use the language properly, but at least, they need to try and improve it through constant repetition. When asked in the interview what type of teaching strategies does he apply in order to enhance classroom interaction patterns, $\mathrm{Mr}$ Nthorela mentioned classroom presentations of topics and debates of the topics being treated.

Mr Nthorela believes that such a strategy is the best possible way to help the learners to be free to clarify complex life sciences concepts with one another and to best understand them. In addition, Mr Nthorela emphasised that this teaching strategy allows the learners to express themselves in the way in which they understand a particular given topic and also helps with motivation and boosts the learners' confidence. However, during the two lessons observed, Mr Nthorela did not use any of the two strategies he mentioned during the interview. The only two methods which were evident in the two lessons observed were code switching and the question and answer method. Unlike Mrs Ngubo, Mr Nthorela prefers both teacher-centred and learner-centred lessons. The way learners engaged in Mr Nthorela's lessons it can be true that learners do engage and participate in Mr Nthorela's lessons on a day-to-day basis. Learners in Mr Nthorela's classes are second speakers of English language, they do not have a rich 
vocabulary of English. Mr Nthorela stated that he would prefer to teach life sciences in Setswana because it will enable him to deliver meaning as intended to his learners. Mr Nthorela acknowledges that his learners struggle to express themselves in English during teaching and learning, having to teach life sciences in a language learners will understand it will help to improve classroom interaction.

\section{Discussions}

Research findings showed that lack of language of teaching and learning affects the level of classroom interactions despite teacher efforts in enhancing classroom interaction. Both teachers recognised the value of using the learners' home languages in their teaching, in order to ensure understanding and engage their learners. This finding confirmed Probyn's (2009) argument that teachers have an obligation to use learners' home languages to explain scientific concepts for meaningful learner understanding. Additionally, during interviews both teachers admitted that their learners never engage in classroom discussions using English, but that they always use their home languages when engaged in discussions. Both teachers mentioned similar methods to enhance classroom interactions in their respective classes on a day-to-day basis, both teachers mentioned classroom presentations and debates of certain scientific concepts as a common strategy they employ in their classes. This is in agreement with Aguiar et al.'s (2010) assertion that learning through group work provides a space where individual rhythms of learning can be taken into account. Group works also provides opportunities to reinforce the understanding of those learners who have already come to understand the scientific view from whole class debate, as these students now try to talk through classmates' questions and objections, which may result in a dialogic interaction pattern. Both teachers emphasised that their choices of strategies were aimed at enhancing classroom interaction, and aimed to help learners build their confidence and boost their self-esteem.

Table 1. An example of the coding and analysis of data from interviews.

\begin{tabular}{|c|c|c|}
\hline Codes & Category & Emerging themes \\
\hline $\begin{array}{l}\text { 1. Give them concepts/topics and they } \\
\text { must go and prepare and come back } \\
\text { and debate about the given concepts } \\
\text { 2. Present to us on what they have } \\
\text { discovered or learned. }\end{array}$ & $\begin{array}{ll}\text { a. } & \text { Code-switching } \\
\text { b. } & \text { Debates } \\
\text { c. } & \text { Classroom } \\
& \text { presentations }\end{array}$ & $\begin{array}{l}\text { Strategies teachers used in } \\
\text { enhancing interaction in } \\
\text { their classes }\end{array}$ \\
\hline $\begin{array}{l}\text { 1. Only attempt to answer in English } \\
\text { whenever I tell them to translate } \\
\text { 2. Big struggle } \\
\text { 3. Few individuals who are smart } \\
\text { participate. }\end{array}$ & $\begin{array}{l}\text { a. Minimum learner } \\
\text { participation. } \\
\text { b. Learners engage in } \\
\text { discussion using their } \\
\text { home languages. }\end{array}$ & $\begin{array}{l}\text { Learners' participation in } \\
\text { class when using English. }\end{array}$ \\
\hline $\begin{array}{l}\text { 1. Allow them to ask in their mother- } \\
\text { tongue and learner participation } \\
\text { increases. } \\
\text { 2. Allow them to code-switch to their } \\
\text { home languages }\end{array}$ & $\begin{array}{l}\text { a. Home-languages } \\
\text { b. Code-switching } \\
\text { when struggling with } \\
\text { English. }\end{array}$ & $\begin{array}{l}\text { Learners preferred to use } \\
\text { their home languages in } \\
\text { classroom discussions. }\end{array}$ \\
\hline $\begin{array}{l}\text { 1. Accepted their responses } \\
\text { 2. Only allow to use their mother- } \\
\text { tongue when I see that they are } \\
\text { struggling }\end{array}$ & $\begin{array}{l}\text { a. Learners are allowed } \\
\text { to code-switch to } \\
\text { their mother-tongue } \\
\text { b. Help the learner to } \\
\text { remember. } \\
\text { c. Increases classroom } \\
\text { Participation on a } \\
\text { day-to-day basis. }\end{array}$ & $\begin{array}{l}\text { Learners allowed to code- } \\
\text { switch to their mother } \\
\text { tongue. }\end{array}$ \\
\hline
\end{tabular}

\section{Conclusion}

The findings revealed that the teachers' choice of teaching strategies during lessons enhanced classroom interaction mostly between teachers and learners. No meaningful learner-learner interactions were observed in the four Grade 11 life sciences classes. During the interviews, the teachers highlighted that their learners hardly participate in class using English. Findings from the interviews revealed that 
both teachers emphasised the use of various methods such classroom debates, presentations, and discussions to enhance interactions in their classrooms. However, the findings from the classroom observations indicated that neither of the teachers used these strategies except for question and answer and code switching strategies. Additionally, findings revealed that teaching and learning of life sciences is still largely teacher-centred, characterised by learner passivity and rote learning, teachers' questioning aims at knowledge recall. The methods teachers mentioned in the interviews were not evident in all four observed lessons.

\section{References}

Aguiar, O. G., Mortimer, E. F. \& Scott, P. (2010). Learning from and responding to students' questions: The authoritative and dialogic tension. Journal of Research in Science Teaching, 47(2), 174-193.

Creswell, J.W. (2009). Research design: quantitative and mixed methods approaches. Third edition. Los Angeles: SAGE.

Gikas, J. \& Grant, M. M. (2013). Mobile computing devices in higher education: Student perspectives on learning with cell phones, smartphones \& social media. The Internet and Higher Education, 19, $18-26$.

Lee, J.F. (2000). Tasks and Communicating in Language Classrooms. Boston: McGraw- Hill Companies.

Pluye, P, \& Hong, Q. N. (2014). Combining the Power of Stories and the Power of numbers. Mixed Methods Research and Mixed Studies Reviews. Annual review Public Health.

Poonam, S. (2017). The use of innovative strategies to enhance quality of classroom interaction. International Journal of Advanced Research and Development, 2(4), 137-141.

Probyn, G. (2016). Language and opportunity to learn science in bilingual classroom in the Eastern Cape. Cape Town: University of Cape Town.

Resane, K. (2016). The socio-cultural functions of indigenous languages in teaching theology. Stellenbosch Theological Journal, 2(1), 2413-9467.

Richards, J. C. (2006). Communicative language teaching today. Cambridge: SEAMEO Regional Language Centre.

Saldana, J. (2009). The coding manual for qualitative researchers. London: Sage Publishers.

Tehmina, B.N. (2003). Manual or electronic? The role of coding in qualitative data analysis. Educational Research, 45(2), 143-154.

Wells, G, \& Arauz, R. (2006). Dialogue in the classroom. Journal of the Learning Sciences, 15(3), $379-428$.

Yore, L, \& Treagust, D. (2006). Current realities and future possibilities: Language and science literacy - empowering research and informing instruction. International Journal of Science Education, 28(2-3), 291-314. 